\title{
Excretion of Eimeria Oocysts in Calves During their First Three Weeks After Turn-out to Pasture
}

\author{
By C. Svensson, P. Hooshmand-Rad, B. Pehrson, M. Törnquist and A. Uggla
}

Experimental Station, Veterinary Institute, Swedish University of Agricultural Sciences, Skara, Department of Parasitology, National Veterinary Institute and Swedish University of Agricultural Sciences, Uppsala, and Animal Health Service, Johanneshov, Sweden.

\begin{abstract}
Svensson, C., P. Hooshmand-Rad, B. Pehrson, M. Törnquist and A. Uggla. Excretion of Eimeria oocysts in calves during their first three weeks after turn-out to pasture. Acta vet. scand. 1993, 34, 175-182. - The numbers of Eimeria oocysts per gram (opg) and the dry matter content of 449 faecal samples taken from 54 calves in 8 herds in south west Sweden were determined during the last 2 weeks before and the first 3 weeks after the animals were turned out to pasture. While they were housed only between 0 and 580 opg were found and in 2 of the herds the numbers of oocysts remained low after turn-out. In the other 6 herds the numbers of oocysts increased after 8 to 10 days and reached a peak of between 1080 and 80803 opg 9 to 18 days after turnout. By 21 to 24 days after turn-out the opg-values had declined to their initial levels. Eimeria alabamensis accounted for most of the increase, but small numbers of oocysts of E. auburnensis, E. bovis, E. bukidnonensis, E. cylindrica, E. ellipsoidalis, E. pellita, E. subspherica, E. wyomingensis and E. zuernii were also observed. The interval between turn-out and the start of the increase in excretion of oocysts corresponded closely to the prepatent period of E. alabamensis and overwintered oocysts were therefore the most likely source of the infection. In 6 of the herds the dry matter content of the faeces of the calves decreased after turn-out and $56 \%$ of the calves had clinical diarrhoea. Although it cannot be excluded that change of diet may have contributed to these symptoms, E. alabamensis infection is suggested as a potential cause of diarrhoea and loss of condition in calves in Sweden during their first weeks on pasture.
\end{abstract}

Coccidiosis; protozoal infection; diarrhoea.

\section{Introduction}

In Sweden diarrhoea is a common problem in calves when they first go out to graze, and has traditionally been thought to be due to the change of diet. In spite of the fact that Eimeria species are known to cause diarrhoea in lambs after they are turned out onto spring pastures (Helle 1964, Gjerde \& Helle 1986) the possible role of these parasites in calves has largely been ignored. However, lambs become affected during their second and third weeks on pasture, whereas calves develop diarrhoea already after a few days on grass. This is the most likely interval for the development of diarrhoea due to a change of diet, but the present authors have observed that calves often excrete large numbers of Eimeria oocysts in their faeces during this period. However, since E. bovis and E. zuernii, the 2 most pathogenic species of bovine coccidia, have prepatent periods of 15 to 21 days ( $L e$ vine 1985) they are unlikely to be the cause of the diarrhoea shortly after turn-out.

The aims of the present study were to identify the species of Eimeria excreted, to examine 
their pattern of excretion and to study their possible clinical significance.

\section{Materials and methods}

The study was conducted during May, June and July 1990, and used 8 dairy herds of Swedish Friesian or Swedish Red and White cows. The herds were selected because they were close to the laboratory in the county of Västergötland in south west Sweden. The numbers of cows in the herds ranged from 24 to 76 , and altogether 54 heifer calves, aged 4 to 16 months, were studied (Table 1). During their first 1 to 2 months of life the calves were housed in individual pens but for the rest of the housed period they were grouped in larger pens or, in herd 3, tethered. The calves were weaned at approximately 2 months of age, except in herd 8 where they were weaned at 6 months. While they were housed the calves were fed concentrates and hay or silage according to traditional recommendations for heifer calves in dairy herds.

Different strategies for turning out were used: in herds 4 and 5 the calves were housed at night during the first week after turn-out, but in the rest of the herds the calves were left out day and night. In all except herd 2 the calves were fed supplementary concentrates or roughage, or both, during the first 1 to 2 weeks of the grazing period. All pastures used had been grazed by calves during the previous summer, and in herds 4 and 8 they had been grazed by heifers, and in herd 2 by cows earlier in the spring. Sustained-release anthelmintic boluses (Paratect vet ${ }^{\circledR}$ ) had been administered to the calves in herds 2, 4 and 6 prior to turn-out. No anticoccidial medication was used during the trial.

Faecal samples were collected once or twice before the grazing period, once during the first week after turn-out and then every other day to every fourth day for 2 to 3 weeks, giving a total of 449 samples. The samples were collected either directly from the rectum or immediately after defecation from pats on the ground. The numbers of oocysts per gram faeces (opg) were counted by a modified McMaster method described by Svensson (1992). The species of Eimeria were identified on the basis of the morphology of the unsporulated oocysts (Joyner et al. 1966). The dry matter content of the faeces was determined by the following procedure: 15 to $20 \mathrm{~g}$ of faeces were weighed in aluminium tins, dried in an incubator overnight at $90^{\circ} \mathrm{C}$, and reweighed to determine the dry matter content. Before the data were analysed statistically the original opg values for each calf were plotted against time after turn-out. The data for the

Table 1. The number of cows in each herd, the numbers of calves studied, their age in months at turn-out, the date of turn-out and the method used to sample faeces.

\begin{tabular}{lccccl}
\hline Herd no. & $\begin{array}{c}\text { No } \\
\text { of cows }\end{array}$ & $\begin{array}{c}\text { No } \\
\text { of calves }\end{array}$ & Age & $\begin{array}{c}\text { Date of } \\
\text { turn-out }\end{array}$ & Sampling method \\
\hline Herd 1 & 24 & 6 & $5-8$ & 17.5 & From the ground \\
Herd 2 & 40 & 5 & $13-16$ & 1.5 & From the ground \\
Herd 3 & 42 & 7 & $9-15$ & 12.6 & From the ground \\
Herd 4 & 76 & 10 & $5-7$ & 14.5 & From the rectum \\
Herd 5 & 25 & 6 & $5-7$ & 24.4 & From the rectum \\
Herd 6 & 46 & 42 & $6-7$ & 4.5 & From the ground \\
Herd 7 & 42 & 4 & $7-9$ & 28.5 & From the rectum \\
Herd 8 & 29 & 4 & & From the ground \\
\hline
\end{tabular}




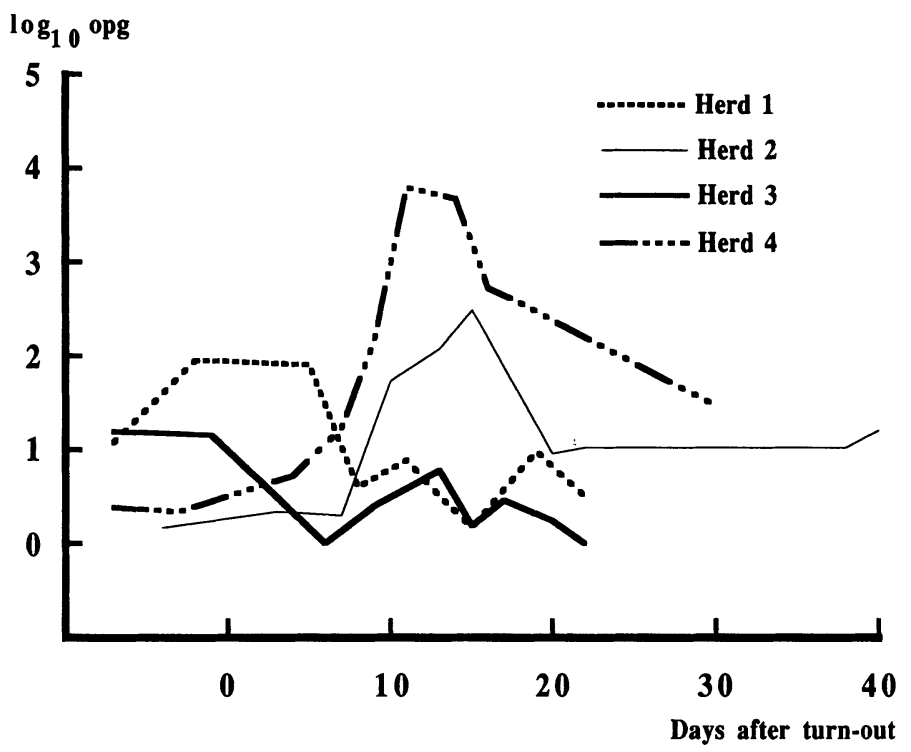

Figure 1. The mean numbers of Eimeria oocysts per gram faeces (opg) of the calves in herds 1-4.

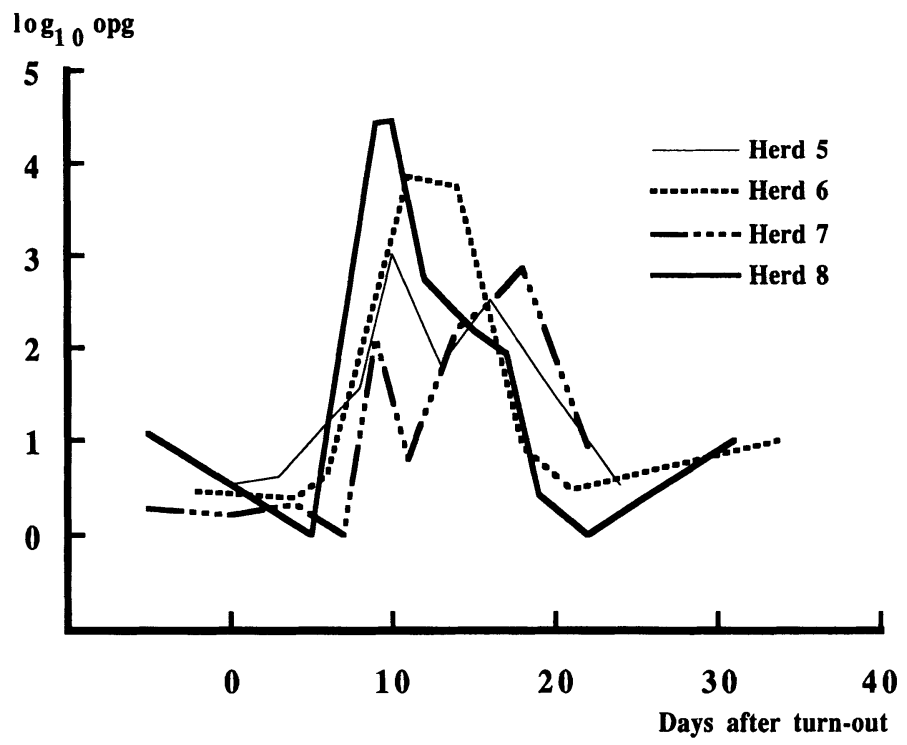

Figure 2. The mean numbers of Eimeria oocysts per gram faeces (opg) of the calves in herds 5-8. 
first 22 days after turn-out were used. The area under the curve (AUC) was calculated by applying the trapezium rule (Altman 1991), with the mean values before turn-out being used as the baseline. The values of the AUC were analysed statistically by means of the Sign test (SAS Institute Inc., Cary, N.C., U.S.A.,1987).

\section{Results}

The mean numbers of oocysts in the faeces of the calves in herds 1 to 4 and herds 5 to 8 are shown in Figs. 1 and 2 respectively. Between 0 and 580 opg were found in the samples taken before turn-out. In herds 1 and 3 the numbers of oocysts remained low after turn-out and in herd 3 even a small decrease was recorded. In the other herds the numbers of oocysts increased 8 to 10 days after turn-out, and in all but herd 7 peak values were observed 9 to 14 days after turn-out. In herd 7 the peak numbers were not recorded until 18 days after turn-out. The increases were significant in herds 4, 5 and 6 (Table 2). After 21 to 24 days the number of oocysts had decreased to values similar to those observed when the calves were still housed. The largest number

Table 2. The mean ( \pm sd) values of the area under the curve (AUC) of the opg values plotted against the number of days on pasture, and the $P$ values for each herd.

\begin{tabular}{lrrl}
\hline & \multicolumn{2}{c}{ AUC } & \\
\cline { 2 - 3 } Herd no. & \multicolumn{1}{c}{$\overline{\mathrm{x}}$} & \multicolumn{1}{c}{ sd } & $\mathrm{P}$ \\
\hline Herd 1 & 790 & 5999 & 0.6 \\
Herd 2 & 27229 & 35767 & 0.06 \\
Herd 3 & -1382 & 2397 & 0.02 \\
Herd 4 & 80925 & 76947 & 0.0005 \\
Herd 5 & 26952 & 29865 & 0.03 \\
Herd 6 & 55991 & 32448 & 0.001 \\
Herd 7 & 6973 & 3781 & 0.1 \\
Herd 8 & 215485 & 231157 & 0.1 \\
\hline
\end{tabular}

of oocysts found in an individual calf was 76,600 opg.

During the peak of oocyst excretion E. alabamensis was the dominant species in all the herds, but small numbers of oocysts of the following species were found throughout the period of sampling: E. auburnensis, E. bovis, E. bukidnonensis, E. cylindrica, E. ellipsoidalis, E. pellita, E. subspherica, E. wyomingensis and E. zuernii.

Before turn-out the consistency of the faeces of nearly all the calves was considered normal, and its mean ( \pm sd) dry matter content was $19.4 \pm 6.5 \%$. The mean dry matter content of the faeces of the calves in herds 1 to 4 and herds 5 to 8 are shown in Figs. 3 and 4 respectively. In herds 1 and 2 no decrease in the dry matter content of the faeces was observed, but in the other herds small to moderate decreases occurred. In these 6 herds clinical diarrhoea was recorded in 24 (56\%) of the calves from 4-15 (mean 8) days after turn-out and in some diarrhoeic calves an obvious loss of condition was seen. A significantly increased oocyst output was observed in 17 (74\%) calves with diarrhoea and in 7 (23\%) calves with normal or just slightly softened faeces.

\section{Discussion}

According to Soekardono (1975) E. alabamensis has a prepatent period of 6 to 8 days, and its sporulation time has been reported to be 4 to 5 days at room temperature (Christensen 1941) or at $27^{\circ} \mathrm{C}$ (Lee \& Armour 1959). During the present investigation these temperatures were reached only during short periods and sporulation therefore must have taken longer. As a result it is very unlikely that reinfection of the calves with oocysts excreted by themselves during their first few days at pasture could have caused the increases in numbers of oocysts, except possibly at the end 


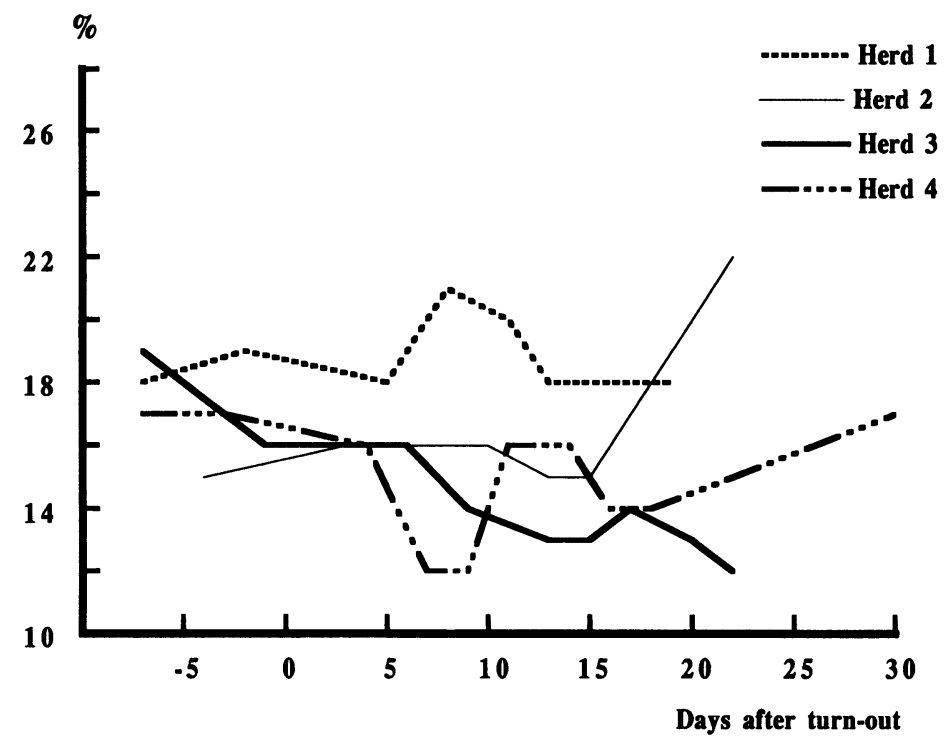

Figure 3. The mean dry matter contents (\%) of the faeces of the calves in herds 1-4.

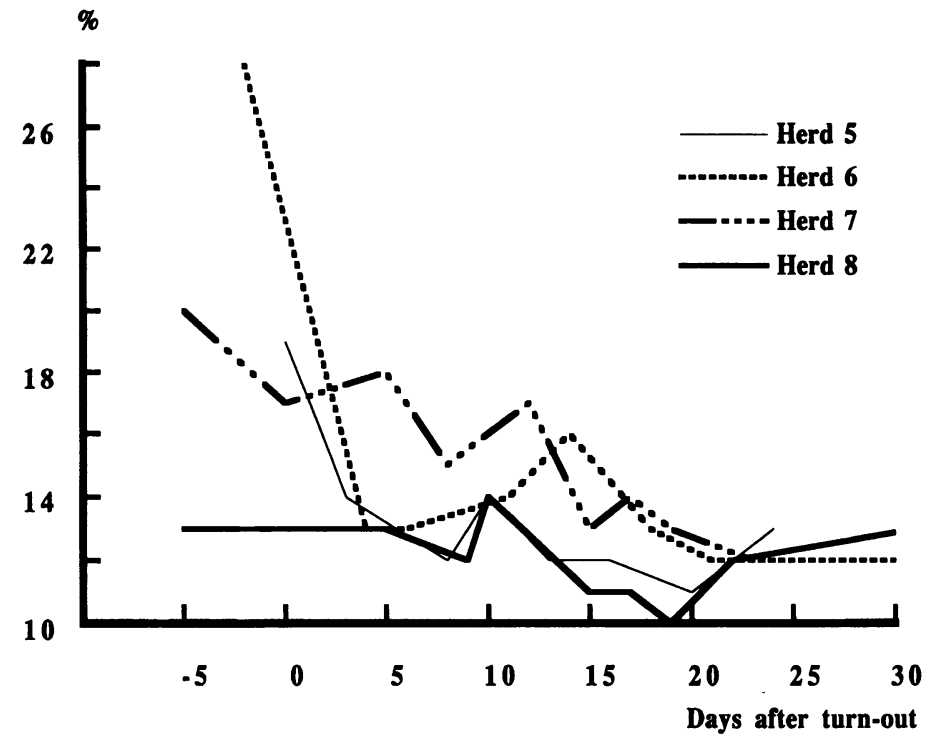

Figure 4 . The mean dry matter contents (\%) of the faeces of the calves in herd 5-8. 
of the period during which they were excreting increased numbers.

The fact that the interval from turn-out to the increase in the output of oocysts corresponded closely with the prepatent period of E. alabamensis suggests that sporulated oocysts on the pastures, ingested during the calves' first few days on grass, were the most likely source of infection. In herds 2,4 and 8 such oocysts might have originated from contamination by animals grazing the pastures earlier in the spring. However, in the other 5 herds the pastures had not been grazed since the previous autumn and sporulated oocysts on the pastures therefore could have originated only from overwintered oocysts. Several authors have reported that coccidial oocysts are resistant to low temperatures; Landers (1953) showed that unsporulated oocysts of E. arloingi, E. ninaekohlyakimovae and $E$. parva from sheep survived freezing to $-19{ }^{\circ} \mathrm{C}$ and to $-25^{\circ} \mathrm{C}$, and concluded that the oocysts would be able to survive the winter in Wyoming, USA. Francalanci (1968) reported that 4 species of sporulated coccidial oocysts of rabbit were viable after being kept for 2 years at $-5^{\circ} \mathrm{C}$, and unsporulated oocysts of E. zurnii of cattle survived for up to 5 months at $-7^{\circ} \mathrm{C}$ (Marquardt et al. 1960). In Sweden it is rare to have long periods of low temperatures without an insulating layer of snow, which further increases the likelihood that oocysts of Eimeria could overwinter. Moreover, Helle (1970) showed that overwintered oocysts could cause coccidiosis in lambs on pasture in Norway, where the climatic conditions are similar to those in Sweden.

The animals shed a few oocysts of E. alabamensis already before they started to graze. It cannot be excluded that the cause of the increase in the excretion of oocysts observed on pasture might have been oocysts ingested during the stable period. Latent infections which could relapse if the animals are stressed have been suggested in the epidemiology of other bovine Eimeria (Levine 1985) and turn-out to pasture is likely to be a considerable stress factor. Moreover, stress from the turn-out could possibly change the pattern of oocyst excretion of an infection contracted by the calves during the last days on stable, as indicated by the works of Long \& Rose (1970) and Niilo (1970).

In the U.S.A. E. alabamensis is generally regarded as non-pathogenic under field conditions, although it has been demonstrated experimentally to be potentially pathogenic (Boughton 1943, Davis et al. 1955). In Germany on the other hand, coccidiosis due to E. alabamensis in animals at pasture have been reported to be an increasing problem (Gräfner et al. 1982). Definite conclusions about the possible clinical significance of E. alabamensis infections in Sweden cannot be drawn on the basis of the present study. The softening of the faeces was observed not only in calves with a significantly increased output of oocysts but also in calves with almost no recorded increase in the output of oocysts. On the other hand, a few calves with a significantly increased output of oocysts had faeces with a normal consistency. The start of the clinical diarrhoea was observed on average 8 days after turn-out, but since samples were taken with relatively long intervals, especially during the first week after turn-out, it is possible that the diarrhoea in fact started some days before it was recorded. In this study none of the calves apparently excreted sufficiently large numbers of oocysts for clinical coccidiosis to be suspected, although it is likely that in some cases the peak of excretion was missed owing to the long intervals between consecutive samples. It deserves to be mentioned that in several other Swedish herds studied by the authors (unpublished findings), E. alabamen- 
sis opg levels of several millions have been recorded in conjunction with severe clinical diarrhoea and even mortality in calves 1 to 2 weeks after turn-out. Further studies are needed to evaluate the role of E. alabamensis as a cause of clinical coccidiosis in young cattle at pasture in Sweden.

\section{Acknowledgements}

The study was financially supported by the Swedish Farmers'Association for Research. Dr. C. C. Norton, Central Veterinary Laboratory, Weybridge, U.K. is gratefully acknowledged for assistance provided at identification of Eimeria species.

\section{References}

Altman DG: Practical statistics for medical research. Chapman and Hall, London, New York, Tokyo, Melbourne, Madras. 1991.

Boughton DC: Sulfaguanidine therapy in experimental bovine coccidiosis. Amer. J. vet. Res. 1943, 4, 66-72.

Christensen JF: The oocysts of coccidia from domestic cattle in Alabama (U.S.A.), with descriptions of two new species. J. Parasitol. 1941, 27, 203220.

Davis LR, Boughton DC, Bowman GW: Biology and pathogenicity of Eimeria alabamensis Christensen, 1941, an intranuclear coccidium of cattle. Amer. J. vet. Res. 1955, 16, 274-281.

Francalanci $G$ : Effect of low temperature on sporulation and survival of the oocysts of Eimeria perforans, media, magna and irresidua. Nuova Vet. 1968, 44, 256-263 (Abstract in Vet. Bull. 1969, 39, abstr. no. 1964).

Gjerde B, Helle O: Efficacy of toltrazuril in the prevention of coccidiosis in naturally infected lambs on pasture. Acta vet. scand. 1986, 27, 124-137.

Gräfner $G$, Graubmann H-D, Kron A, Müller $H$, Daetz H-H., Plötner J, Benda A: Zum Auftreten der Weidekokzidiose in Jungrinderbeständen. (Pasture coccidiosis in young cattle). Mh. Vet.Med. 1982, 37, 776-779.

Helle O: Coccidiose hos sau. (Coccidiosis in sheep). Medlemsbl. norske Veterinaerforen. 1964, 16, 117-127.
Helle $O$ : Winter resistant oocysts in the pasture as a source of coccidial infection in lambs. Acta vet. scand. 1970, 11, 545-564.

Joyner LP, Norton CC, Davies SFM, Watkins CV: The species of coccidia occurring in cattle and sheep in the South-West of England. Parasitology 1966, 56, 531-541.

Landers EJ: The effect of low temperatures upon the viability of unsporulated oocysts of ovine coccidia. J. Parasitol. 1953, 39, 547-552.

Lee RP, Armour J: The coccidia oocysts of Nigerian cattle. Brit. vet. J. 1959, 115, 6-17.

Levine ND: Veterinary Protozoology. Iowa State University Press, London 1985.

Long PL, Rose ME: Extended schizogony of Eimeria mivati in betamethasone-treated chickens. Parasitology 1970, 60, 147-155.

Marquardt WC, Senger CM, Seghetti L: The effect of physical and chemical agents on the oocysts of Eimeria zurnii. J. Protozool. 1960, 7, 186-189.

Niilo $L$. The effect of dexamethasone on bovine coccidiosis. Can. J. comp. Med. 1970, 34, 325-328.

Soekardono S: The prepatent and patent periods of Eimeria alabamensis and further description of the exogenous stages. Vet. Parasitol. 1975, 1, 1933.

Svensson C: Peripartal excretion of Eimeria oocysts by cows on Swedish dairy farms and the age of calves at first excretion. Acta vet. scand. 1993, 34, 77-81.

\section{Sammanfattning}

Utsöndring av Eimeria oocystor hos kalvar under deras första tre veckor efter betessläppning

Antalet Eimeria-oocystor per gram (opg) och torrsubstanshalten bestämdes i 449 träckprover från 54 kalvar i 8 besättningar i sydvästra Sverige under de sista 2 veckorna före och de första 3 veckorna efter betessläppning. I prover tagna då kalvarna stod på stall hittades endast mellan 0 och 580 opg och i 2 besättningar förblev antalet oocystor lågt efter betessläppningen. I de övriga 6 besättningarna ökade antalet oocystor efter 8 till 10 dagars betesgång och nådde en topp på mellan 1080 och 80803 opg 9 till 18 dagar efter betessläppningen. Tjugoen till 24 dagar efter betessläppningen hade antalet oocystor sjunkit till ursprunglig nivå. Eimeria alabamensis ansvarade för den största delen av ökningen. Oocystor av E. auburnensis, E. bovis, E. bukidnonensis, E. cylindrica, E. ellipsoidalis, 
E. pellita, E. subspherica, E. wyomingensis och E. zuernii observerades i lågt antal. Intervallet från betessläppning till den ökade oocystutsöndringen motsvarade prepatensperioden hos E. alabamensis (6-8 dagar), varför övervintrade oocystor var den mest sannolika infektionskällan. I 6 av besättningarna sågs sänkningar av träckens torrsubstans- halt och några kalvar uppvisade klinisk diarré. Även om det inte kan uteslutas att foderbytet bidragit till dessa symptom, dras slutsatsen att infektion med E. alabamensis kan misstänkas utgöra en potentiell orsak till diarré och konditionsnedsättning under de första veckorna efter betessläppning hos förstagångsbetande kalvar i Sverige.

(Received January 7, 1993; accepted January 14, 1993).

Reprints may be requested from: C. Svensson, Experimental Station, Veterinary Institute, Swedish University of Agricultural Sciences, P. O. Box 234, S-532 23 Skara, Sweden. 